\title{
Optical combustion sensor data interpretation using hybrid negative selection algorithm with artificial immune networks
}

\author{
Lytvynenko V. ${ }^{1}$, Smolarz A. ${ }^{2}$, Wójcik W. ${ }^{2}$, Ballester J. ${ }^{3}$, Kozhukhovskaya O. ${ }^{4}$, Gromaszek K. ${ }^{2}$ \\ ${ }^{1}$ Kherson National Technical University \\ 24 Bereslavsk Road, Kherson, Ukraine \\ ${ }^{2}$ Lublin University of Technology \\ 38a Nadbystrzycka str., 20-618, Lublin, Poland \\ ${ }^{3}$ University of Zaragoza \\ 3 Maria de Luna str., 50018 Zaragoza, Spain \\ ${ }^{4}$ Cherkasy State Technological University \\ 460 Shevchenko Avenue, Cherkasy, Ukraine
}

(Received 25 February 2015)

\begin{abstract}
In most extended in Poland PC burners an individual air excess ratio rules an amount of pollution generated, yet there is a lack of method that allows measurement of output parameters. It is therefore necessary to use indirect methods, which could primarily include acoustic, and optical methods. These methods are non-invasive and can provide virtually not delayed and additionally spatially selective information about the combustion process but they are really difficult in interpretation. The article shows application of relatively new class of classification methods - the artificial immunology algorithms to the combustion process diagnostics consisting in detection of incorrect air excess in pulverised coal burner on the basis of signals acquired from optical sensor.
\end{abstract}

Keywords: optical industrial systems, industrial diagnostics, pulverised coal burner, artificial immune network, negative selection algorithm

2000 MSC: $68 \mathrm{~T}$

UDC: $519.6: 681.51 .015$

\section{Introduction}

Power industry and coal based especially has its important share in air pollution. In order to decrease an amount of toxic substances originated in a combustion process the so-called low emissive combustion technology has been introduced. It generally consists in gradual supply of air, in order to create reduction zones in a flame, what reduces emission of gaseous pollutants e.g. like NOx. The main advantage of such modifications is relatively low investment cost. Unfortunately, such technology has some adverse side effects. In order to minimise their consequences it is necessary to obtain information about the course of combustion process as well as its adequate control. Both tasks are relatively difficult because of high complexity of the phenomena proceeding during combustion. Commonly used control systems employ process variables such as: flow of the air-pulverised coal mixture from each mill, air fans load, unit power or emission of gasses $\left(\mathrm{CO}, \mathrm{O}_{2}, \mathrm{NOx}\right)$. There are also attempts to include some related values e.g. near wall gas composition [1,2]. However, in spite of big complexity, all these systems have one basic disadvantage: the control is based on averaged and heavily delayed measurements. Even the most advanced of recently available control systems is not able to control an individual burner, while an individual air excess ratio rules an amount of NOx generated.

The analysis of the problem let us conclude that there is a lack of method that allows measurement of output parameters of an individual burner like for example air excess level. It is therefore necessary to use indirect methods, which could primarily include acoustic, and optical methods. These methods are non-invasive and can provide virtually not delayed and additionally spatially selective information 
about the combustion process. The biggest disadvantage of such method is the problem of interpretation of signals obtained. Artificial immunology algorithms are relatively new class of classification methods. This article describes their application to the combustion process diagnostics consisting in detection of incorrect air excess in pulverised coal burner.

\section{Optical fflame sensor}

The estimation of the NOx content within the flame of an individual burner based on the emission spectrum analysis is possible, yet it can be hardly done in harsh, industrial conditions, especially high temperature, vibrations and dustiness are present. Additionally combustion of pulverized coal in the power burner takes place in a turbulent flow. In its each point local fluctuations of both fuel and gaseous reactants concentrations as well as of temperature occur. It leads to permanent local changes in the combustion process' intensity, which result in continuous changes in the flame luminosity that can be observed as the flame flicker. As the combustion process affects the turbulent movement of its products and reactants it determines the parameters of the way the flame flickers such as e.g. mean luminosity and luminosity frequency spectrum. A number of combustion supervision and flame-fault protection systems use information contained within the flame flicker. A multichannel fibre-optic flame monitoring system developed at the Lublin University of Technology is an example of a solution of that kind [3].

The aforementioned system is designed for operations in harsh conditions. It provides signals corresponding to radiation generated within spatially limited flame zones. Generally, the systems consist of the following elements: measuring probe, optical fibre bundle, photodetectors, and signal processing unit. Schematic diagram of a typical flame monitoring system is presented in fig. 1. A measuring probe is placed inside a combustion chamber, close to a burner and is exposed to temperatures in the order of hundreds degrees centigrade. Its construction ensures a long-term operation inside the combustion chamber by the air that purges the probe front. Solid angles from which the radiation is delivered to the photodetectors are determined by the place where the probe is installed and the numerical aperture of the optical fibres applied. The probe's orientation is adjusted so as to provide the highest signal susceptibility to the changes in the combustion process e.g. the equivalence ratio. A photograph of a multichannel measuring probe is shown in fig. 2 .

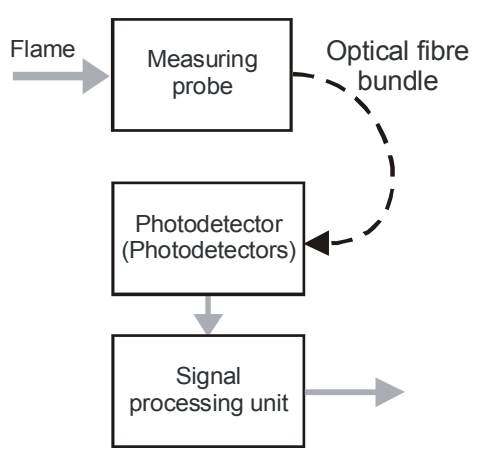

Fig. 1. Schematic diagram of a flame monitoring system.

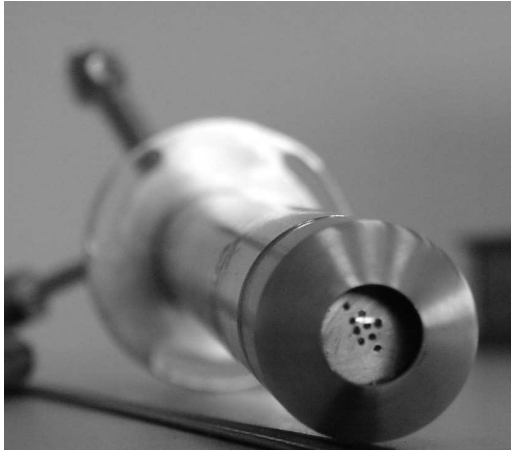

Fig. 2. Multichannel measuring probe.

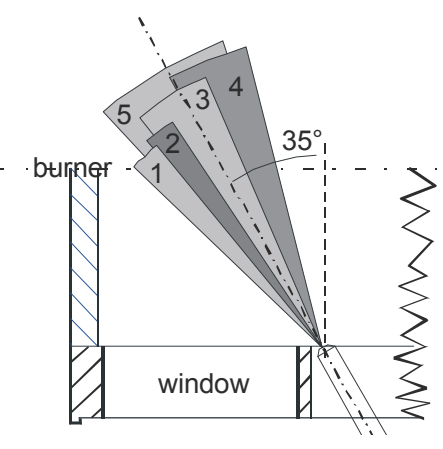

Fig. 3. Areas of view of fibers.

An optical fibre bundle enables to separate the signal processing unit from high temperatures inside the combustion chamber enabling more flexible mounting of the whole system. As the length of the fibres applied is in the order of a few meters, the attenuation of the optical signal within a spectral range of the radiation emitted by a coal flame can be neglected. To maximize the radiation power acquired by the measuring probe a thick-core PCS or HCS were used for their maximum temperature up to $350^{\circ} \mathrm{C}$. 
To detect coal flame radiation, photodetectors designed for the visible or the near-infrared range are suitable. Materials such as $\mathrm{Si}, \mathrm{Ge}$, InGaAs or the so called modified silicon are commonly used. The latter one has better performance in the UV range, so it may be applied also for the fuel-oil flame detection. The spectral characteristic of the photodetector applied is presented in fig. 3. To minimize the influence of electromagnetic noise in industrial conditions and to simplify the construction of an electronic part of the whole device, it is better to apply a photodetector with an integrated operational amplifier.

In the signal processing unit, a signal obtained from the photodetector is amplified at an adjustable level. The flame monitoring system is insensitive to interferences of both the adjacent flames and the hot elements of the boiler.

\section{Artificial immune algorithms}

The Artificial Immune Systems, as defined by de Castro and Timmis [4] are: "Adaptive systems inspired by theoretical immunology and observed immune functions, principles and models, which are applied to problem solving". However AIS are one of many types of algorithms inspired by biological systems, such as neural networks, evolutionary algorithms and swarm intelligence. There are many different types of algorithms within AIS and research to date has focused primarily on the theories of immune networks, clonal selection and negative selection. These theories have been abstracted into various algorithms and applied to a wide variety of application areas such as anomaly detection, pattern recognition, learning and robotics.

\subsection{Negative selection algorithm}

The negative selection of T-cells is responsible for eliminating the T-cells whose receptors are capable of binding with self-peptides presented by self-MHC molecules. This process guarantees that the T-cells that leave the thymus do not recognize any self-cell or molecule. Forrest et al. [5] proposed a change detection algorithm inspired by the negative selection of T-cells within the thymus. This procedure was named as negative selection algorithm and was originally applied in computational security. A single type of immune cell was modelled: T-cells were represented as bit strings of length $L$. The negative selection algorithm of Forrest and collaborators is simple [5]. Given a set of self-peptides, named selfset $\mathbf{S}$, the T-cell receptors will have to be tested for their capability of binding the self-peptides. If a T-cell recognizes a self-peptide - it is discarded, else it is selected as an immune-competent cell and enters the available repertoire $\mathbf{A}$.

The idea of negative selection algorithm is to generate a set of detectors in a complementary set of $\mathbf{N}$ and then to use these detectors for binary classification as "Self" or "Non-Self" [5]. Formally, the negative selection algorithm can be represented as [6]:

$$
N e g A l g=\left(\Sigma^{L}, L, \mathbf{S}, \mathbf{N}, r, n, s, p r\right)
$$

where $\Sigma^{L}$ denotes shape-space; $L$ is receptor length; $\mathbf{S}$ is "Self" detector set; $\mathbf{N}$ is "Non-Self" detector set; $r$ denotes cross-reactive threshold; $n$ is total number of appointed detectors; $s$ is detector set size; pr denotes rule matching rows in adjacent positions.

The negative selection algorithm can be summarized as follows [5]:

- Define self as a collection $\mathbf{S}$ of elements in a feature space $\mathbf{U}$. a collection that needs to be monitored. For instance, if $\mathbf{U}$ corresponds to the space of states of a system represented by a list of features, $\mathbf{S}$ can represent the subset of states that are considered as normal for the system.

- Generate a set $\mathbf{F}$ of detectors, each of which fails to match any string in $\mathbf{S}$. An approach that mimics the immune system generates random detectors and discards those that match any element in the self set. 
- Monitor $\mathbf{S}$ for changes by continually matching the detectors in $\mathbf{F}$ against $\mathbf{S}$. If any detector ever matches, then a change is known to have occurred, as the detectors are designed not to match any representative samples of $\mathbf{S}$.

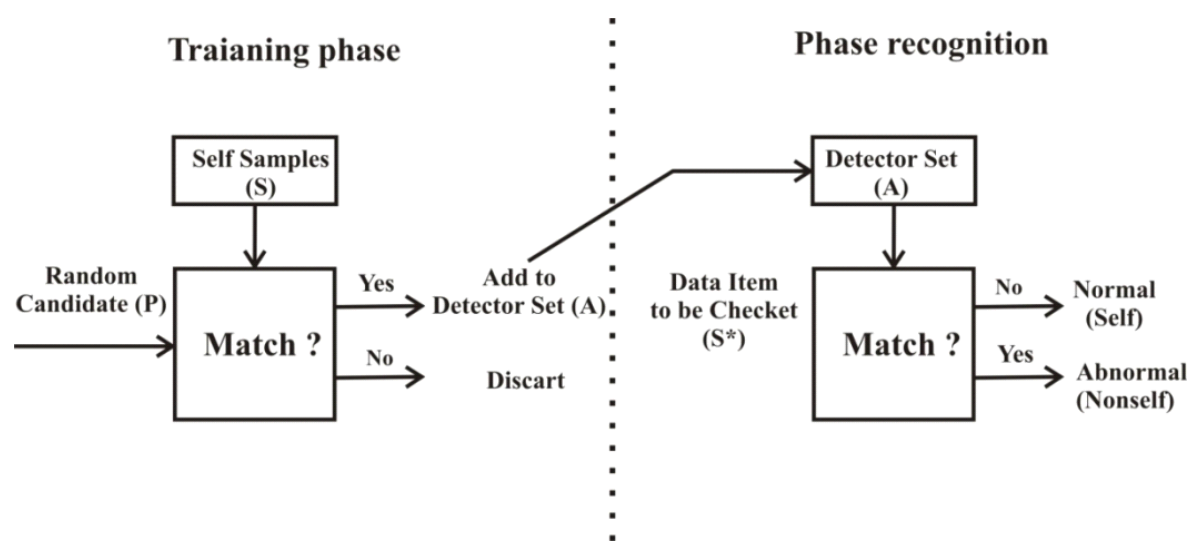

Fig. 4. Negative selection algorithm [7].

\subsection{Artificial immune network algorithm}

Immune network can be presented mathematically as a graph (moreover, not obligatory fully connected), which consists of the set of nodes, i.e., cells of network (antibodies) and the set of weighted edges, denoting connections between cells [6]. The value of edge weight corresponds to affinity of connection of cells with each other. One distinguishes two types of affinity in immune networks:

- affinity of connection "antigen-antibody" $\mathrm{Ag}-\mathrm{Ab}$ is degree of difference;

- affinity of connection "antigen-antibody" $\mathrm{Ab}-\mathrm{Ab}$ is degree of similarity.

Formalism of immume network is similar to CLONALG wit addition of several new operators and parameters [8]:

$$
i m m N E T=\left(P^{l}, G^{k}, l, k, m_{A b}, \delta, f, I, \tau, A G, A B, S, C, M, n, d, H, R\right),
$$

here $P^{l}$ is the space of search (space of forms); $G^{k}$ is representation of the space; $l$ is the length of vector of attributes; $k$ is the length of receptor of cell; $m_{A b}$ is size of cells population; $\delta$ is the expression function; $f$ is the affinity function; $I$ is the function of initialization of the initial population of network cells; $\tau$ is the condition of completion of algorithm work; $A G$ is subset of antigens, $A B$ is population of network cells (antibodies); $S$ is the operator of selection; $C$ is the cloning operator; $M$ is the mutation operator; $n$ is the number of the best cells selected for cloning, $d$ is the number of the worst cells subject to substitute by new ones; $H$ the operator of the clonal removal; $R$ is the operator of network compression.

Behavior of immune network in many respects differs from behavior of the clonal selection algorithm, which stepwise realization is represented below.

1. Initialization.

1.1. Creation of the initial population of cells of memory $M_{R}$.

1.2. Creation of population of antibodies $(A B)$.

2. Antigen presence. Starting from this block algorithm realizes one pass at a time for every antigen.

2.1. Determination of affinity. Affinity is determined for all cells of memory $m_{j}, m_{j} \in M_{R}$ for regular antigen $A g_{i}, A g_{i} \in A G$ and one the best cell $m_{b}$, is selected.

2.2. Cloning. The selected cell of memory is cloned proportionally to its affinity with generation of population of clones $M_{C}$. 
2.3. Maturation of affinity. Mutation of clones from $M_{C}$ is performed. Changed clones are added to population of antibodies, i.e., $A B \leftarrow A B \cup M_{C}$. Affinity of population of antibodies $A B$ with the antigen $A g$, is determined.

2.4. Methadynamics. Clonal removal of nonstimulated cells is done in accordance with the threshold $\sigma_{d}$.

2.5. Repeated cloning of a part of antibodies from the population $A B$ with generation of clones population $M_{C}$ and transition to items 2.3 if mean affinity of the population $A B$ is lower than the given threshold value.

2.6. From the population $A B$ the cell-candidate (the best antibody) is selected into population of cells of memory $A b_{b}$.

2.7. Go to item 3 if $f\left(A b_{b}, A g_{i}\right)<f\left(m_{b}, A g_{i}\right)$.

2.8. Addition of antibody $A b_{b}$ into the population $M_{R}$.

2.9. Cell-cell interaction. Affinity of interaction of all cells of population $M_{R}$ with each other is determined, i.e., $f\left(m_{i}, m_{j}\right), m_{i}, m_{j} \in M_{R}$.

2.10. Network compression. Recognizing each other cells of population $M_{R}$ are removed according to the given threshold $\sigma_{S}$

3. Verification of the condition of stoppage of the algorithm and passing to item 2, if the condition does not hold.

\subsection{Combined immune network and negative selection algorithm}

It is well known, that the algorithm of negative selection (NS) has the some restrictions and limitations [7]. When it is not appropriate, for example, the number of self samples is small and sparse.

Some limitations of the binary-string representation in NS algorithms are as follows: binary matching rules are not able to capture the semantics of some complex self/non-self spaces; it is not easy to extract meaningful domain knowledge; in some cases a large number of detectors are needed to guarantee better coverage (detection rate); it is difficult to integrate the NS algorithm with other immune algorithms; the crisp boundary of "self" and "non-self" may be very hard to define.

In real-valued representation the detectors are represented by hyper-shapes in n-dimensional space. The algorithms use geometrical spaces and use heuristics to distribute detectors in the non-self space.

Some limitations of the real-valued representation in NS algorithms are: the issue of holes in some geometrical shapes, and may need multi-shaped detectors; curse of dimensionality; estimation of the coverage; selection of the distance measure.

In this study, concerns the problem of developing improved methods of generating detectors capable adaptively choose their adjustment, the number and location.

Modification of the learning phase in the model of negative selection [9, 10]. Solving a specific problem with the help the generalized $m$ requires specific descriptions of some operators and functions. In this case, the immune network uses encryption antibodies with the help real numbers, when to calculate the distance used Euclidean metric. This antibody forms around a radial $l$-dimensional region recognition with a radius $r$, called cross-reactive threshold. As shown in Figure 5, cross-reactive threshold was included in the structure of antibodies, what enables of adaptive setting its value. Thus, the immune network fills space "Non-self", which are recognized by hyper spheres of different radius, that enables its more complete coverage.

\begin{tabular}{|l|l|l|l|l|}
\hline $\mathrm{r}$ & $A b_{i 1}$ & $A b_{i 2}$ & $\cdots$ & $A b_{i l}$ \\
\hline
\end{tabular}

Fig. 5. Presentation of the immune network antibody.

To calculate the affinity values of the relationship "antigen-antibody" the following ratio is used:

$$
f_{A b-A g}=\frac{k_{r}}{r}+D_{E(A b-A g)},
$$


where $r$ is the cross-reactive antibodies (detector) threshold, $k_{r}$ is coefficient of importance of crossreactive threshold (parameter settings). Parameter $k_{r}$ is very important study parameter. He manages the robustness of the resulting solution. Increasing this parameter causes the immune network to maintain larger radius detectors, what gives a coarser, but more sustainable solution. However, excessive increase of $k_{r}$ affects negative to the accuracy of solutions.

Compress of immune network is based on self-recognition cells that is numerically expressed as affinity relationship of antibody with each other. To calculate the values of affinity relationship "antibodyantibody" proposed the following formula:

$$
f_{A b-A b}=-\frac{D_{E\left(A b_{1}-A b_{2}\right)}-\left(r_{A b_{1}}+r_{A b_{2}}\right)}{2 \cdot \min \left(r_{A b_{1}}, r_{A b_{2}}\right)},
$$

$$
\begin{gathered}
f_{A b-A b}<=0- \\
\text { Compression is not } \\
\text { required }
\end{gathered}
$$

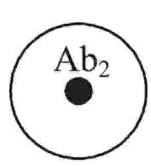

$$
\begin{gathered}
0<f_{A b-A b}<1-\text { Compression } \\
\text { depends on degree of } \\
\text { overlapping of detectors }
\end{gathered}
$$
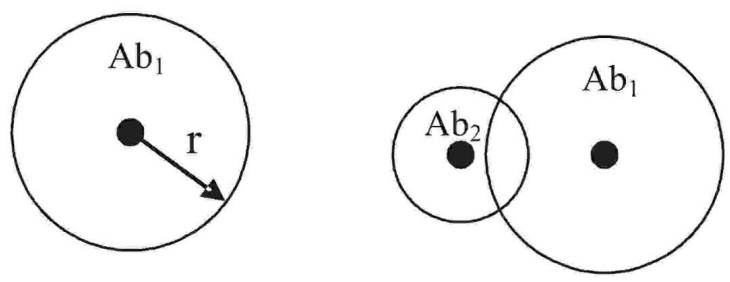
$f_{A b-A b}>=1-$ Compression by removal of the absorbed detector is made

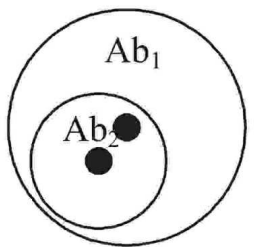

Fig. 6. Different mutual arrangement of the recognizing hyper sphere of detectors depending on the value $f_{A b-A b}$.

This possible interpretation of such values $f_{A b-A b}: \leqslant 0$ - recognizing hyper sphere detectors do not overlap. This option does not require compression, because the antibodies do not recognize each other; $(0,1)$ - hyper sphere overlap by shells, namely the value is the degree of overlap. This compression is dependent on the value of the parameter of threshold compression $\sigma_{s}$, which is a parameter of study; $\geqslant 1-$ hyper sphere smaller radius $(r)$ is completely inside hyper sphere larger radius. In this case, compression is definitely needed, because there is redundancy recognizing elements. This operator $\mathrm{H}$ of clonal deletion acts only those antibodies that recognize at least one antigen. Thus, the resulting immune network at the end of each generation is guaranteed to not contain detectors that recognize "their" antigens.

Solution to the problem of binary classification. In general, the problem of anomaly detection can be represented as follows [9-11]. Let this discrete time series variables of the process $y_{1}, y_{2}, \ldots, y_{n}$. Assumed that the discrete control variable $y(t)$ is carried out on the range $\left[t_{1}, t_{n}\right]$. At some chosen temporal window width $k$ measurements $(k<n)$. The value of time series, which trapped inside the time window, forming a feature vector $Y_{t}\left(y_{t}, y_{t-1}, \ldots, y_{t-k+1}\right)$. Feature vector is assigned membership in one of two classes: normal(1) if the sample time series corresponding to this vector does not contain anomalies (i.e., belongs to a class of "Self"), abnormal(0) otherwise. Temporary window shifts (slips) along the time series on value steps of $\Delta l$, forming a set of vectors that divide attribute space into two parts, with or without abnormalities. The problem lies in attributing any vector $Y_{j}$ formed by sliding time window to one of two selected classes. On the other hand, if we consider the study process as a dynamic system is obtained by sliding window set of vectors is the restored phase portrait of dynamical system, and the same vectors - points that are phase trajectories of the system.

In normal behavior, this trajectory can be interpreted as a reference image, whatever deviation from which is a sign of abnormality. It should be emphasized that the use of negative selection is not necessary to include in the training sample vectors corresponding to the anomalous behavior that makes it possible to fix any, even unknown anomaly (non-self). 


\section{Training phase}

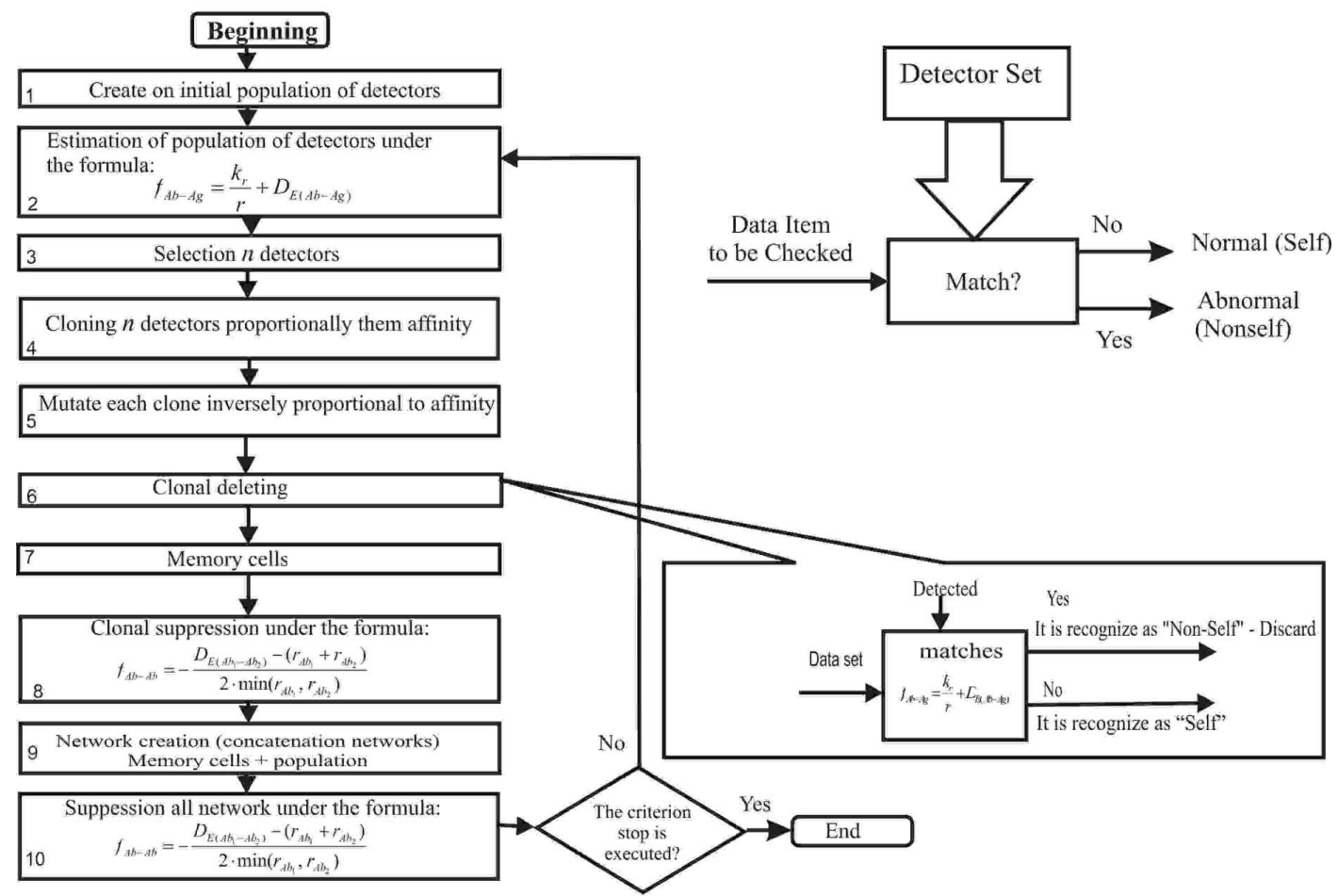

Fig. 7. Generalized block-diagram of the hybrid procedure of the immune network with a negative selection.

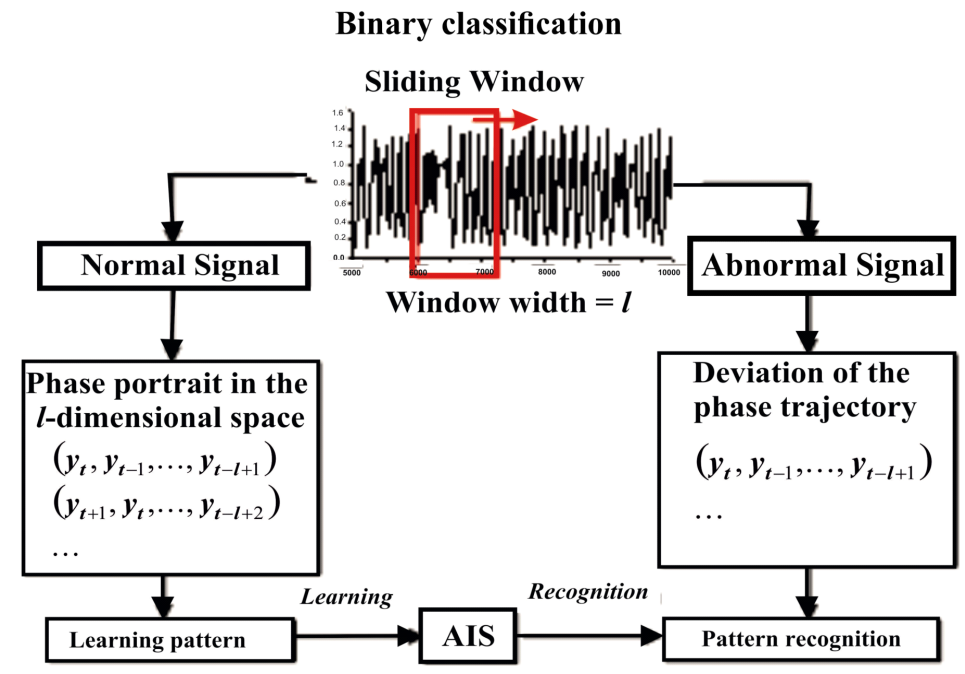

Fig. 8. The task of binary classification of a signal.

\section{Test methodology and facility}

Combustion of pulverized coal was examined through optical methods, which were based on analysis of wide spectrum radiation emitted by the flame. The analysis also takes into account spatial features of such radiation source. Combustion of pulverized coal in the power burner takes place in a turbulent flow. In its each point local fluctuations of both fuel and gaseous reagents concentrations, as well as temperature occur. It leads to permanent local changes in combustion process intensity, which result 
in continuous changes in flame luminosity that can be observed as flame flicker. As combustion process affects the turbulent movement of its products and reagents it determines the way the flame flicker parameters such as e.g. mean luminosity and luminosity frequency spectrum. A number of combustion supervision and flame-fault protection systems use information contained within flame flicker. The multichannel fibre-optic flame monitoring system developed at Lublin University of Technology belongs to this class of solutions but additionally it allows observation of selected areas of the flame.

Experiments were made on test rig located in the Institute of Power Engineering in Warsaw. It is a combustion chamber with a single pulverized coal swirl burner made in 1:10 scale in relation to a low-emission industrial burner. This object was chosen because of the ability to perform experiments with a single burner, and it's a good instrumentation. All measured quantities are visualized and recorded by the data acquisition system. Sampling period is $1 \mathrm{~s}$. The combustion chamber is equipped with the above mentioned optical fibre probe which allows observation of five different areas of the flame. Figure 3 shows section of part of the chamber with marked areas of view.

\section{Measurements}

The experiment begins with bringing the chamber to the proper temperature. When the temperature stabilizes the series of measurements are performed with changing air and fuel flows. During an individual measurement the amounts of fuel and air are kept constant. A single measurement lasts approximately 300 seconds. Such a measurement method is to eliminate the impact of the transport delay of gas analysers. It is assumed that during the measurement the conditions are fixed and the emission values stabilized. The tests were made at three different thermal loads, for pure pulverised coal and $10 \%$ blend with biomass (shredded straw). The amount of secondary air was being changed in order to achieve the air excess corresponding to normal operation, too high and too low conditions. Voltage signals corresponding to the instantaneous brightness of the flame of the areas observed by individual optical fibres were sampled at the rate of $8 \mathrm{KS} / \mathrm{s}$ and saved by a dedicated system. Figure 9 shows example measurements corresponding to normal, too low and too high air excess ratio. A set of features was randomly divided into learning and testing subsets by $30 \% / 70 \%$ and $70 \% / 30 \%$.

Table 1. Class distribution of the data points in the training and testing datasets.

\begin{tabular}{|c|c|c|c|}
\hline Class & Training set & Testing set & Total \\
\hline \hline$\lambda$ too high & 720 & 1680 & 2400 \\
\hline$\lambda$ correct & 720 & 1680 & 2400 \\
\hline$\lambda$ too low & 720 & 1680 & 2400 \\
\hline Total & 2160 & 5040 & 7200 \\
\hline \hline$\lambda$ too high & 1680 & 720 & 2400 \\
\hline$\lambda$ correct & 1680 & 720 & 2400 \\
\hline$\lambda$ too low & 1680 & 720 & 2400 \\
\hline Total & 5040 & 2160 & 7200 \\
\hline \hline$\lambda$ too high & 1920 & 480 & 2400 \\
\hline$\lambda$ correct & 1920 & 480 & 2400 \\
\hline$\lambda$ too low & 1920 & 480 & 2400 \\
\hline Total & 5760 & 1140 & 7200 \\
\hline
\end{tabular}

In order to avoid the bias associated with the random sampling of the training data the $k$-fold cross-validation was also performed. In $k$-fold cross-validation, the data is partitioned into $k$ subsets of approximately equal size. Training and testing the algorithm is performed $k$ times. Each time, one of the $k$ subsets is used as the test set and the other $k-1$ subsets are put together to form a training set. Thus, $k$ different test results exist for the algorithm. However, these $k$ results are used to 

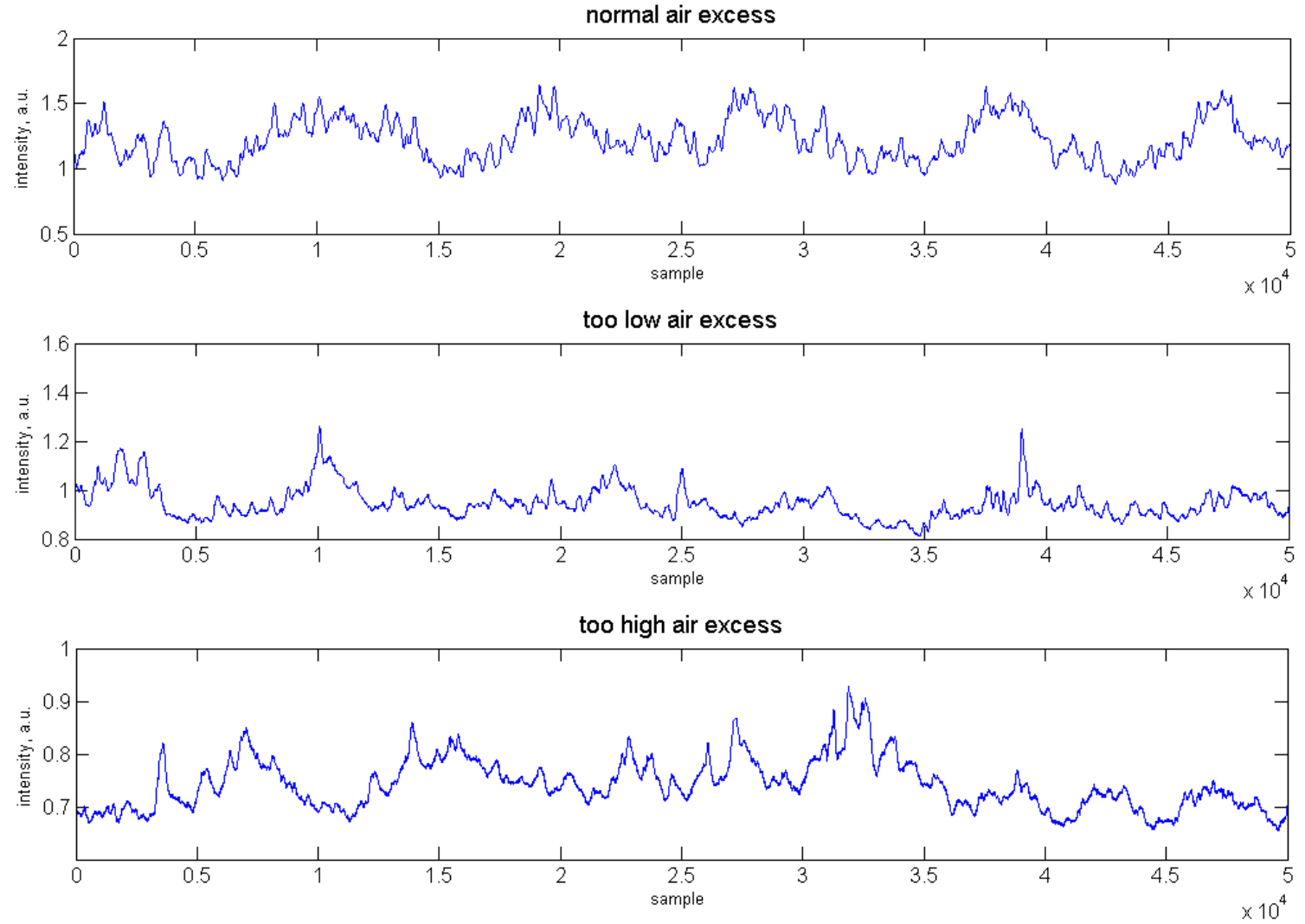

Fig. 9. Example measurements corresponding to normal, too low and too high air excess ratio.

estimate performance measures for the classification system. Table 1 contains class distribution of the data points in the training and testing datasets.

The common performance measures used in diagnostics are accuracy, sensitivity and specificity. Accuracy expresses the ability of the classifier to produce accurate diagnosis. The measure of the ability of the model to identify the occurrence of a target class accurately is determined by sensitivity. Specificity is determined the measure of the ability of the algorithm to separate the target class. The accuracy can be expressed as:

$$
\operatorname{Accuracy}(Z)=\frac{\sum_{i=1}^{|z|} \operatorname{Assess}\left(z_{i}\right)}{|Z|}, \quad \operatorname{Assess}(z)= \begin{cases}1, & \text { if } \operatorname{classify}(z)=z . c \\ 0, & \text { otherwise }\end{cases}
$$

where $z$ denotes the patterns in testing set to be classified, $z . c$ is the class of pattern $z, \operatorname{classify}(z)$ returns the classification of $z$ by classification algorithm. For sensitivity and specificity analysis, the following equations can be used:

$$
\text { Sensitivity }=\frac{\mathrm{TP}}{\mathrm{TP}+\mathrm{FN}}, \quad \text { Specificity }=\frac{\mathrm{TN}}{\mathrm{TN}+\mathrm{FP}},
$$

where TP, TN, FP and FN denote respectively true positive, true negative, false positive and false negative classification.

Many discriminative methods, including Support vector machine, neural network and classifiers based on the artificial immune systems, are often most accurate and efficient when dealing with two classes only (they can deal with more classes, but usually at reduced accuracy and efficiency). For large number of classes, higher-level multi-class methods are developed that utilize these two-class 
classification methods as the basic building blocks. To solve our problem, we used the strategy of one-versus-all based on the hybrid algorithm we developed negative selection and artificial immune network [12]. The simplest approach is to reduce the problem of classifying among $K$ classes into $K$ binary problems, where each problem discriminates a given class from the other $K-1$ classes [13]. For this approach, we require $N=K$ binary classifiers, where the $k$ th classifier is trained with positive examples belonging to class $k$ and negative examples belonging to the other $K-1$ classes. When testing an unknown example, the classifier producing the maximum ouput is considered the winner, and this class label is assigned to that example. Rifkin and Klautau [13] state that this approach, although simple, provides performance that is comparable to other more complicated approaches when the binary classifier is tuned well [14].

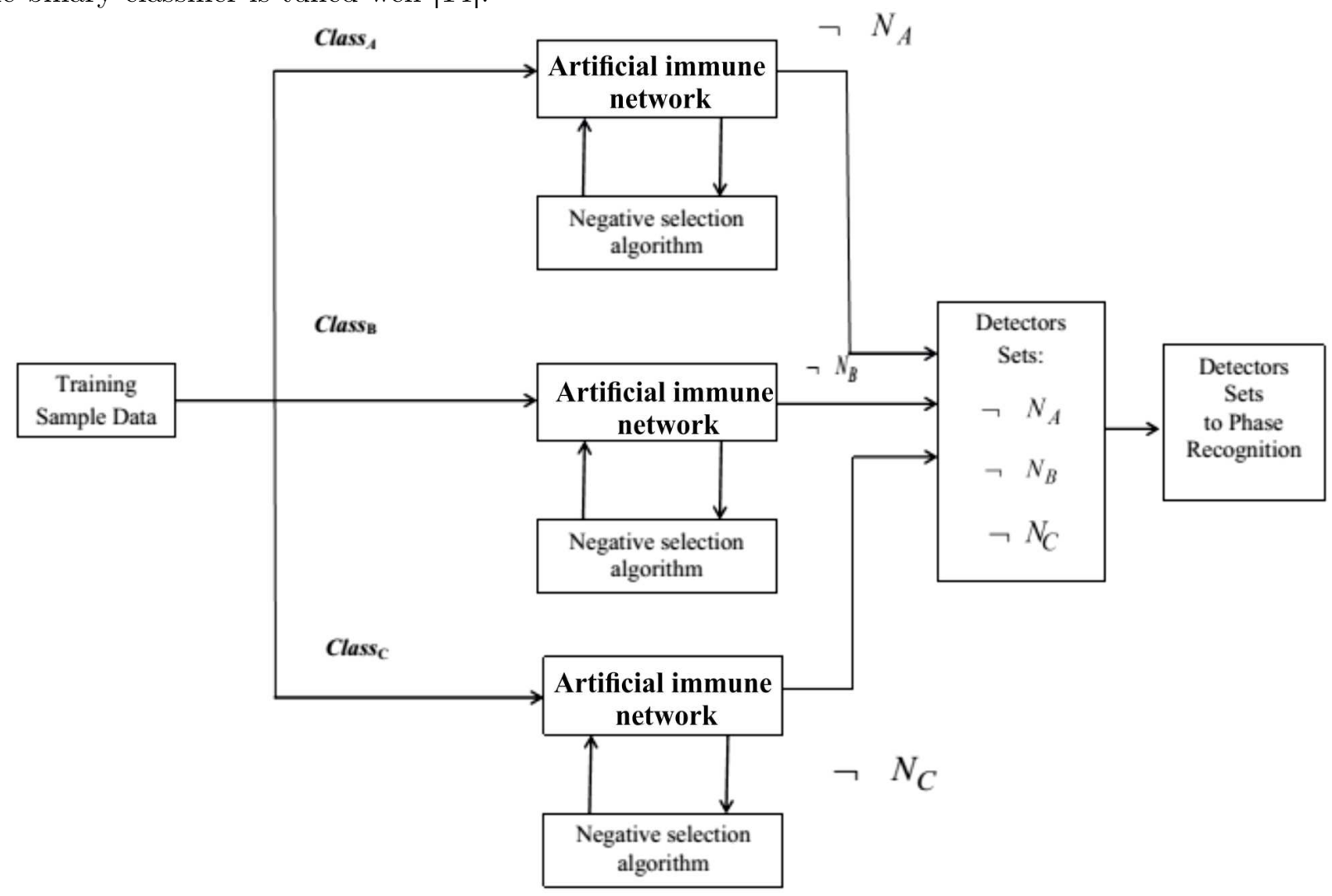

Fig. 10. Synthesis of adaptive binary classifiers - learning phase in negative clonal selection algorithm.

\section{Results}

Classification tests using modification of the learning phase in the model of negative selection were made according to the algorithm shown in Fig. 5. Table 2 contains the results of performance analysis. Average accuracy was about $98.99 \%$. Classification accuracy obtained using fuzzy networks (TSK) was about $96.4 \%$ [15]. Normalised execution time of both algorithms was similar.

Table 2. Performance measures for negative clonal selection algorithm.

\begin{tabular}{|c|c|c|c|}
\hline learning set/testing set distribution & accuracy & sensitivity & specificity \\
\hline \hline $40 / 60$ & 98.96 & 99.30 & 99.15 \\
\hline $60 / 40$ & 99.16 & 99.20 & 99.55 \\
\hline $80 / 20$ 5-fold cross-validation & 98.88 & 98.75 & 99.35 \\
\hline mean & 98.90 & 99.07 & 99.30 \\
\hline
\end{tabular}




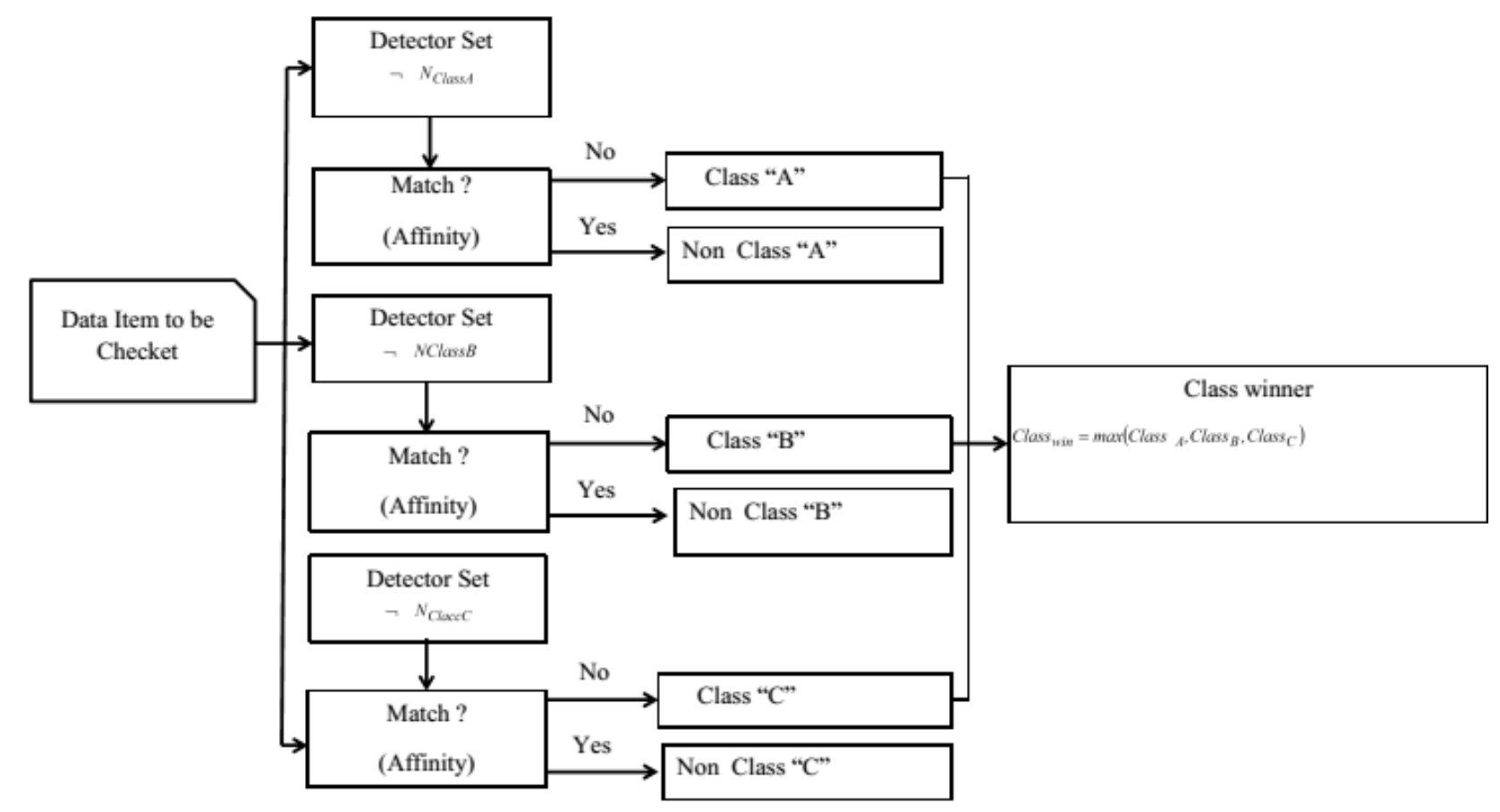

Fig. 11. Classification phase in negative clonal selection algorithm.

\section{Conclusions}

Optical signal can be used for operation status detection of an individual burner. The optical signal is the fastest and provides a selective way of getting information about the quality of combustion. Its interpretation, however, poses many difficulties.

The modification of the learning phase in the model of negative selection that uses optimization as well as the artificial immune network for optimization parameters detectors are developed. A distinctive feature of this procedure is a modification of the learning process, due to which is implemented the adaptive selection settings, the number and location of detectors. Experimental studies have shown high efficiency of the proposed procedure, which is evident in its stability through adaptive value of cross-reactive threshold; optimality due to the adaptive immune network configuration size, i.e. the number of required detectors; accuracy by reducing the number and size created "cavities".

Classification accuracy of the modification of the learning phase in the model of negative selection was better than one of fuzzy (TSK) algorithm when applied to the problem of detection of anomalies in air excess ratio using optical system. Considering similar computational complexity of above mentioned algorithms the advantage of the former one is clear. The modification of the learning phase in the model of negative selection combined with optical methods can then be used for diagnostics of correct cofiring of pulverised coal blends with biomass in individual PC burner.

\section{Acknowledgements}

A part of the research leading to these results has received funding from the European Union's Research Fund for Coal and Steel (RFCS) research programme under contract n ${ }^{\circ}$ RFCR-CT-2008-00009SMARTBURN.

[1] Komada P. and Cieszczyk S. Application of Multiple Line Integrated Spectroscopy on CO Concentration Measurement. Elektronika ir Elektrotechnika. 19(9), 46-49 (2013).

[2] Komada P., Cikszczyk S. and Wójcik W. Influence of gas concentration inhomogeneity on measurement accuracy in absorption spectroscopy. Przegląd Elektrotechniczny. 88(8), 36-38 (2012). 
[3] Wójcik W., Surtel W., Smolarz A., Kotyra A., Komada P. Optical fiber system for combustion quality analysis in power boilers. Proceedings of SPIE 4425, 517-522 (2001).

[4] De Castro L. N. and Timmis J. Artificial Immune Systems: A New Computational Intelligence Approach. Springer, London, England. 1-357 (2002).

[5] Forrest S., Perelson A. S., Allen L. and Cherukuri R. Self-nonself discrimination in a computer. Proceedings of the Symposium IEEE Computer Society on Research in Security and Privacy, May 16-18, IEEE Xplore Press, Oakland, CA., USA. 202-212 (1994). DOI: 10.1109/RISP. 1994.296580

[6] Lytvynenko V.I. Comparative experimental study of a modified negative selection algorithm and clonal selection algorithm negative for solving classification. Vestnik Kherson National Technical University. 4(33), 7-11 (2008). (In Russian)

[7] Dasgupta D. Advances in Artificial Immune Systems. IEEE Computational Intelligence Magazine. 1(4), 40-49 (2006).

[8] Bidyuk P. I., Lytvynenko V. I. and Fefelov A. O. Formalizatsiya metodiv pobudovi shtuchnix imunnih systems. Naukovi Visti Natsionalnogo tehnichnogo universitetu Ukraine Kiivsky politehnichny institut. 1/2007, 29-41 (2007).

[9] Lytvynenko V., Bidjuk P. and Myrgorod V. Application of the method and combined algorithm on the basis of immune network and negative selection for identification of turbine engine surging. 2nd International Conference on Inductive Modelling. Kyiv, Ukraine. 116-123 (2008).

[10] Fefelov A. A., Litvinenko V. I. and Bidjuk P. I. Modification of algorithm of negative selection on the basis of mechanisms artificial immune sets for the decision of problems of detection of anomalies. The Collection of scientific jobs in five volumes of the second international scientific conference Intellectual systems of decision-making and applied aspects of information technologies. Evpatoria, 19-22 May, 2007. 3, 73-78 (2007).

[11] Lytvynenko V. Classification systems based on negative selection mechanism. III International Scientific and Practical Conference Trends in Research. Dnipropetovsk, 21-30 June 2004. 34-36 (2004).

[12] Ding C. H. Q. and Dubchak I. Multi-class protein fold recognition using support vector machines and neural networks. Bioinformatics. 17(4), 349-358 (2004).

[13] Rifkin R. and Klautau A. Parallel networks that learn to pronounce English text. Journal of Machine Learning Research. 5, 101-141 (2004).

[14] Aly M. Survey on Multi-Class Classification Methods. Technical Report, Caltech, USA (2005).

[15] Smolarz A. Optical methods in diagnostics of combustion process of gaseous fuels, pulverized coal and its blends with biomass. Wydawnictwo Politechniki Lubelskiej. Lublin, Poland. 99-100 (2013). (In Polish) 


\title{
Інтерпретація даних оптичних датчиків моніторінгу горіння 3 використанням гібридного алгоритму негативного добору штучних імунних мереж
}

\author{
Литвиненко В. ${ }^{1}$, Смоляч А. ${ }^{2}$, Вуйцик В. ${ }^{2}$, Балестер X. ${ }^{3}$, Кожуховська O. ${ }^{4}$, Громашек K. ${ }^{2}$ \\ ${ }^{1}$ Херсонський начіональний технічний університет \\ Береславське шосе, 24, м. Херсон, 73008, Украӥна \\ ${ }^{2}$ Технічний університет «Люблінсъка політехніка» \\ вул. Надбистрицька, 38а, 20-618, м. Люблін, Польша \\ ${ }^{3}$ Сарагозький університет \\ вул. Марія де Луна, 3, м. Сарагоза, 50018, Іспанія \\ 4 Черкасъкий державний технологічний університет \\ Бульвар Т. Шевченка, 460, м. Черкаси, Україна
}

У найпоширеніших у Польщі промислових котлах кількісна характеристика забруднення під час горіння здійснюється за допомогою «коефіцієнта надлишку повітря». Однак, сьогодні відсутні будь-які методи, які б дали змогу вимірювати вихідні параметри, які безпосередньо давали б можливість визначати якість горіння. 3 цієї причини, значно цікавить використання акустичних і оптичних методів для оцінювання якості горіння. Зазначені методи належать до класу так званих «неівазивних» методів, які дають змогу, з одного боку, дистанційно і миттєво отримувати великий обсяг інформації про горіння, але, з іншого боку, в разі їх застосування виникають проблеми інтерпретації отриманих даних. У статті описано застосування нового гібридного імунного алгоритму для виконання завдань діагностики процесу горіння. Запропонований алгоритм дає можливість виявити надлишок повітря в казані з розпорошеним вугіллям на основі оброблення сигналів, отриманих від оптичного датчика.

Ключові слова: оптичні індустріальні системи, промислова діагностика, горілки вугільного пилу, штучні імунні системи, алгоритм негативного добору

2000 MSC: $68 \mathrm{~T}$

УдК: 519.6:681.51.015 